\title{
Plenary lecture on the wise production and use of metals is
}

\author{
Theo Lehner* \\ Boliden Mineral AB, Rönnskär Smelter, SE 93281 Skelleftehamn, Sweden \\ Lulea University of Technology, Division of Process Metallurgy, SE 97187 Luleå, Sweden \\ Received 16 March 2007; accepted 19 March 2007 \\ Available online 17 May 2007
}

\begin{abstract}
The modern art of metal production engages a broad range of disciplines and knowledge: metallurgy and technology, environment, health and safety, economics and juris prudence, personnel and politicians, in short, a good example of modern industrial management. A historical perspective will be used to outline the author's vision. Boliden operates two smelters in Sweden as part of its integrated mining, smelting, refining and recycling business. Boliden's history includes births, learning, first love, tough decisions, and a recent marriage! The learning curve for the Rönnskär smelter just passed its 75 th birthday. It well illustrates the everlasting efforts of our industries to stay on-line with the global industrial learning curve. As part of the society we live and operate in, we fulfil the task of a supplier of metals that man needs. As corporate citizens we also dare to express our concerns if things go wrong, be it in politics or in environmental matters. As the employer of choice we have to create a living organization attracting young operators and engineers as well. As a producer we have to act for the responsible use and recycling of our products. As wisdom comes of age but is about the future, challenges to be turned into opportunities will be forwarded - and hopefully discussed.
\end{abstract}

(C) 2007 Elsevier Ltd. All rights reserved.

Keywords: Smelting; Sustainability; Wise; Learning curve; Long living companies

\section{Introduction}

"The technological solution to sustainability" is the subtitle of this symposium. It arrived in my hands about the same time as an article in "Foreign Affairs" about "Recovering Sustainable Development". As far I did not recognize Foreign Affairs as the most revolutionary journal, but when reading the paper I felt it was hitting reality on the nail (Victor, 2006): "as sustainable development has become conventional wisdom over the past two decades, something has gone horribly wrong. Because the concept stresses the interconnection of everything, it has been vulnerable to distortion by woolly thinking and has become a magnet for special interest groups. Human rights watchdogs, large chemical companies, small island nations, green

\footnotetext{
Edited by M.A. Reuter.

* Address: Boliden Mineral AB, Rönnskär Smelter, SE 93281 Skelleftehamn, Sweden.

E-mail address: Theo.Lehner@boliden.com
}

architects, and nuclear power plant operators have attached themselves to the fashionable notion only to subvert it for their own ends. Instead of bringing together nature, the economy, and social justice, sustainable development has spawned over-specialized and largely meaningless checklists and targets".

Support for this statement can be found when analyzing the literature. Fig. 1 shows the "learning curve" for the term "sustainable development".

Some of us may remember another "hot term" a couple of years ago: "acid rain". The development of the popularity of that term is given in Fig. 2.

A critical reader would pose the question: how come that the Research Community suddenly realizes a problem? How come that that issue develops like a snowball down the hill? Or does the development rather mirror the financing potential of a term?

One conclusion is that even modern researchers would gain from digging in libraries and reading older stuff, also older than oneself. (A typical "forgetting curve" of 


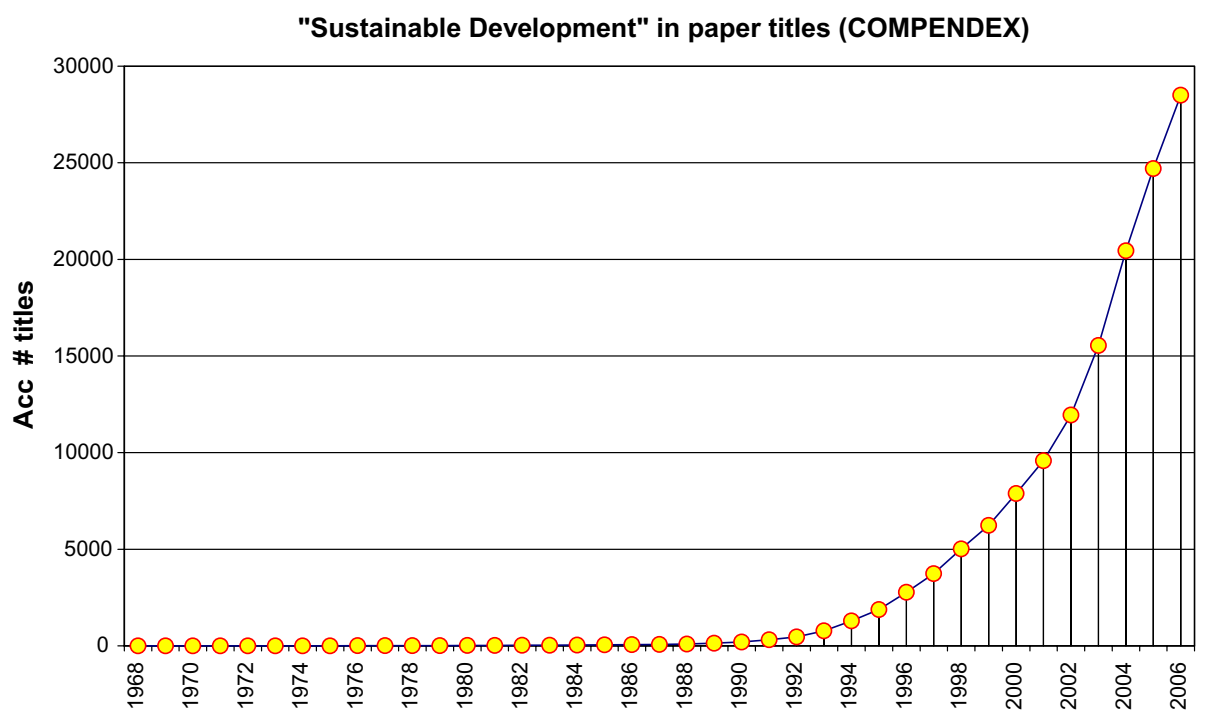

Fig. 1. Titles in Compendex Database with term "sustainable development".

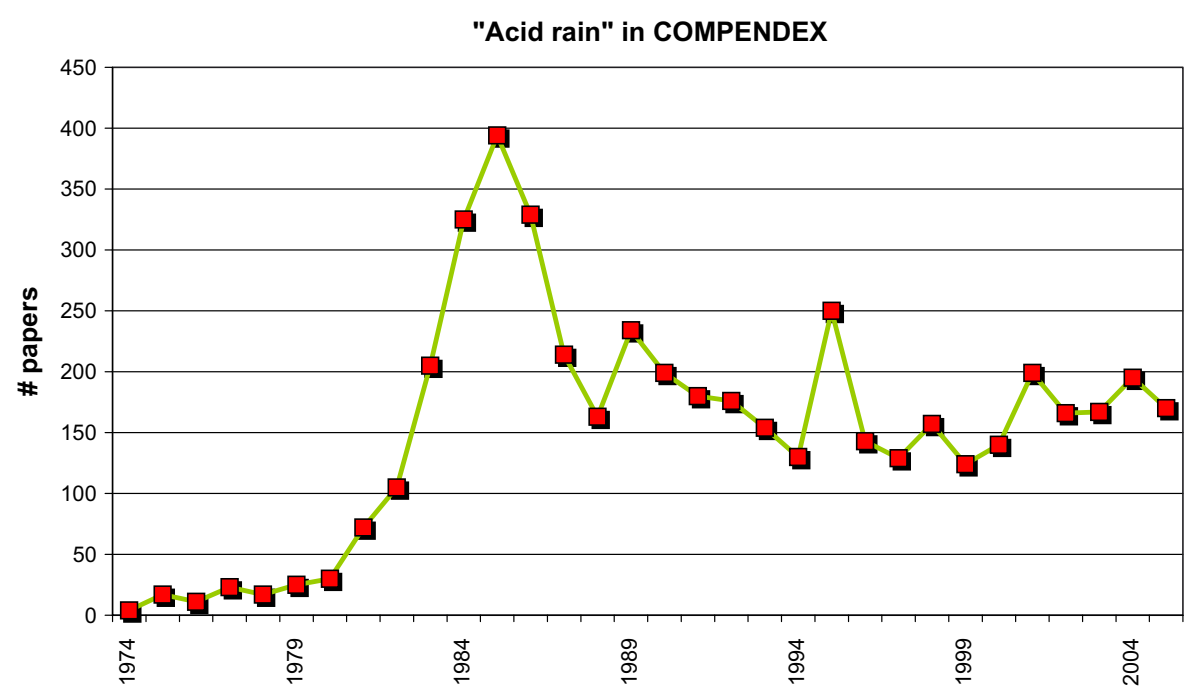

Fig. 2. Titles in Compendex database with term "acid rain".

research as shown in e.g., conference proceedings shows that (a) the references are mostly auto-references, (b) seldom older than five years.)

With this in mind, you could check the date of the following statement by Van Hise (with slight change in wording not to make your guess too easy): "The first fact about conservation of resources is that it stands for development. There has been a fundamental misconception that this means nothing but the husbanding of resources for future generations. Real conservation demands the welfare of this generation first, but also the welfare of the generations to follow". With this in mind, it would be wise to strengthen the historical education of our becoming engineers. Not to load them with historical facts, but to turn them a little more humble in realizing that we stand on the shoulders of the achievements of our ancestors. We still pay for some of their mistakes, but even more, we profit from their work.

\section{From Y's to wise}

To aid in a more critical assessment of the flow of information, we more often should ask the three Why's? (i) Why this? (ii) Why he/she? And (iii) Why now? Table 1 gives some recent "hot objects" in the media, in politics or in $\mathrm{R} \& \mathrm{D}$ together with possible answers on the Y's.

From Table 1, I draw the conclusion that we need more research. Independent research, that puts the questions, points at as well industry, NGO's, governments and fellow researchers: you are wrong! In approaching the title of this paper, we need to give thoughts on what is "wisdom". A short definition by an Indian Chieftain is concise: 
Table 1

3 Y's exemplified: Why this? Why he/she? Why now?

\begin{tabular}{|c|c|c|c|c|}
\hline Object & Issuer & Y1 & Y2 & Y3 \\
\hline Lead free green TV & OEM & Sell more & Sell more & RoHS \\
\hline Feedstock $=$ not recycling & Composters & Sell more & Limit competition & Waste directive \\
\hline Back fill = material use & Salt mines & Sell more & Owner of cavity & EOL directives \\
\hline Re-use of EOL & OEM & Sell more & Owner of problem & WEEE directive \\
\hline Refine waste oil & Refineries & Sell more & Owner of capacity & Waste Oil Directive \\
\hline Green electricity & Power companies & Sell at higher price & More income & Greenhouse effect times \\
\hline No car wash at home & Gas stations & Sell more & Owns wash strait & Draught \\
\hline SD R\&D & Universities & More funds & Need of funds & Lack of funds \\
\hline
\end{tabular}

"Knowledge is about the past - wisdom is about the future" (Arden et al., 1990), or in poetic terms by Eliot (1934):

Where is the life we have lost in living?

Where is the wisdom we have lost in knowledge?

Where is the knowledge we have lost in information?

As it is neither my profession nor the interest of this conference to dig into philosophy ("=enjoy science") but still may be thought provoking, some more references to the definition of wisdom are added in the reference list, easily available on the World Wide Web (e.g. WWW1). Naturally we hope, and believe, that "common sense" and "wisdom" prevail. We also hope that long-livedness of ideas, concepts, or, companies, are signs of wisdom. Within the subject of this conference, we concentrate on the business aspects.

\section{Long living companies}

Long living companies, according to De Geus (1999) (i) are sensitive to the business environment they live in, (ii) cohesive with a strong sense of identity, (iii) tolerant with lean management structures and (iv) conservative in financing. Long living, for businesses, has been defined to be more than 12 years. Yet some companies are much older than that. The oldest Swedish Shareholding company has it's origin in the Falu Copper mine. Mine life was from before (700? AD) 1550 until 1992. The oldest documentation of a shareholder dates to 1288 (Lindström, 2002). Though payment was not in cash, but in flour mills, fishing rights and forests. Today, the offsprings of that company, STORA ENSO are back into the forests, have quit mining, but still use products and by-products from mining.

Is Boliden a long lasting company? You may check yourself: Boliden is the result from a gold rush in Northern Fennoscandia in the early 1920 's. Are we sensitive to the business environment we live in? Fig. 3 illustrates one case of continued adaptation: the source of value creation changed over times - and will do so continuously. Do we have a strong sense of identity? I can tell you that our units have strong identities! Do we have lean management structures? At least we doubled the size of the company recently without doubling the number of layers. Yet we need to keep a close watch on the company phone list, without becoming

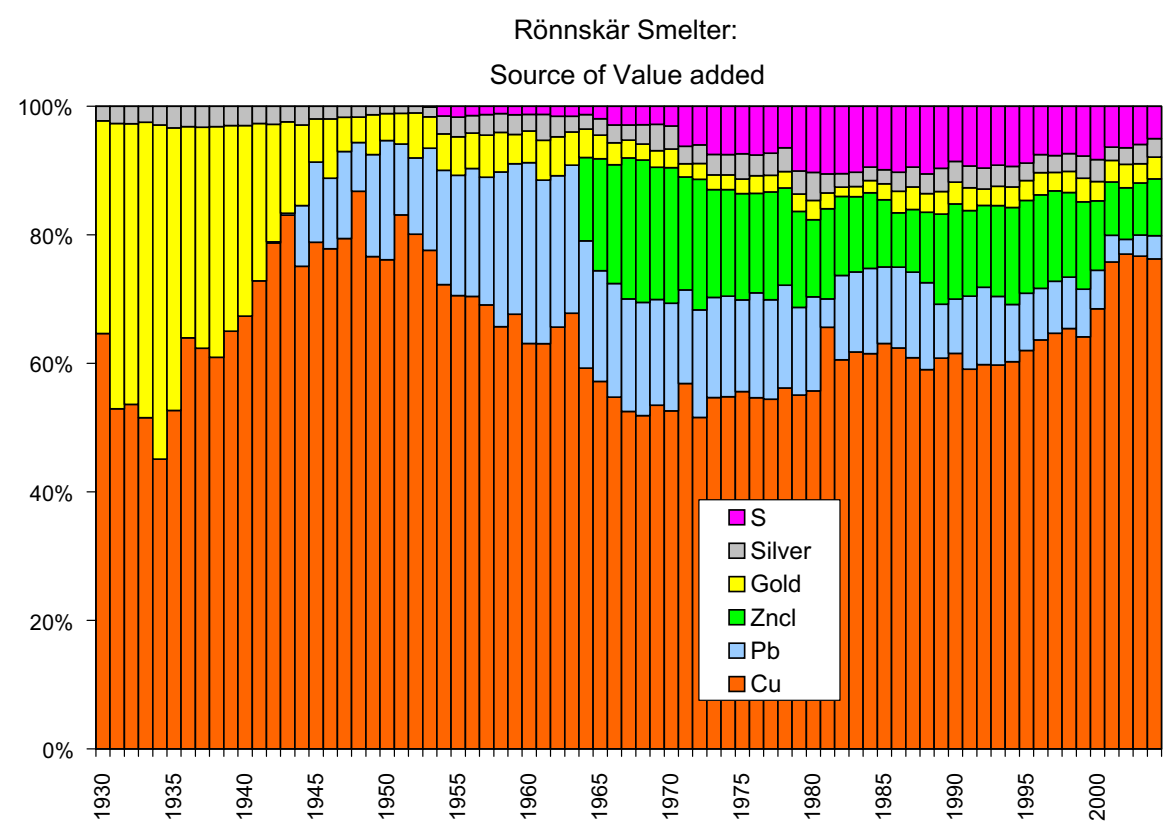

Fig. 3. Adaptation to changing markets and raw materials illustrated by the source of value added to our Rönnskär Smelter. 
"anoretic" and knowing that, around the corner of present heydays of high metal prices may well lay new challenges. Are we conservative in financing? This is a dull chapter part in Boliden's recent past: costly takeover battles, experiments, like moving to Canada, buying "cheap assets" combined with the unfortunate mine spill at our then being Spanish Mine nearly brought Boliden to the company graveyard. A rescue operation was initiated by a Swedish industrial financier, by local authorities, unions and management. During the rescue, an opportunity arose: the strong identities of (old) Boliden and (old) Outokumpu wanted to marry! So the two companies decided to check each other's assets.

New Boliden emerged in 2004 as the result of the successful integration of the mining, smelting and recycling operations of Swedish Boliden AB and Finnish Outokumpu OY. Soon after three years of joint operations, we have realized foreseen synergy benefits, and continue to detect new ones. Long living management is in a sense about management of capital (MMSD Project, 2002), which include natural, manufactured, human, social and financial, respectively. Hence the question to Boliden as a long living company is: what have we done the last 70 years?

Boliden has

- strived to be profitable,

- constantly tried to integrate the economic, social and environmental goals,

- extracted and recycled metals which society needs, and

- worked hard to manage the various forms of capital put with trust in our hands.

Naturally, we best like the comment made in the same document (MMSD Project, 2002): “...the prices paid for products must reflect the true costs of providing them".

\section{Industrial learning curves}

The integration of the economic, social and environmental goals combines challenges such as: (i) varying metal prices with a steady downward trend, (ii) changing foreign exchange rates, (iii) acceptance of industrial activities, and (iv) legislation covering long-term and momentous issues.

The longstanding answer to the above is, again, adaptation and steady improvements. This is nothing new. Swedish metallurgical history is well documented. Also another, yet threatening finding is called "Horndahl effect": the directors at this Swedish Steel Plant at Horndahl found that profitability and productivity increased, year by year, without spending any capital. But, as you guess, this holds for some years, then reality catches up: the Horndahl open hearth steel plant is closed. So is the Robertsfors blast furnace (Fig. 4). Reasons for closure were changing costs, limits to growth by technology, and changing world markets.

In the case of the Rönnskär smelter, productivity gains have been achieved by methods of growth and rationalization. Fig. 5 illustrates that periods of increased production follow periods of personnel reduction, but also changes in technology.

Examples of major technological changes: addition of slag fuming, addition of fluidized bed roasting, permanent cathode technology, copper and lead flash smelting. Examples of rationalization: reduction of number of acid plants and number of units hot, closing of electric lead smelting and lead bullion converting, closing of copper Kaldo smelting.

Interestingly, some of the major improvements of productivity were achieved as a consequence of new, tougher environmental demands set by authorities in renewed permits. Summarizing we have to say: the environmental improvements over the last decades have not come in spite of - but rather thanks to production increases. Also to underline is the successful nature of the Swedish permitting system: setting limits rather than prescribing details has demonstrated to be very successful to both business and the environment. Unfortunately, recent political developments within the EU rather prefer bureaucratic detail regulation than goal-setting umbrellas. (Ask the 3 Y's for the reasons...!) A comparison of the learning curves for productivity and environmental impact reveals that the two go hand in hand (Fig. 6).

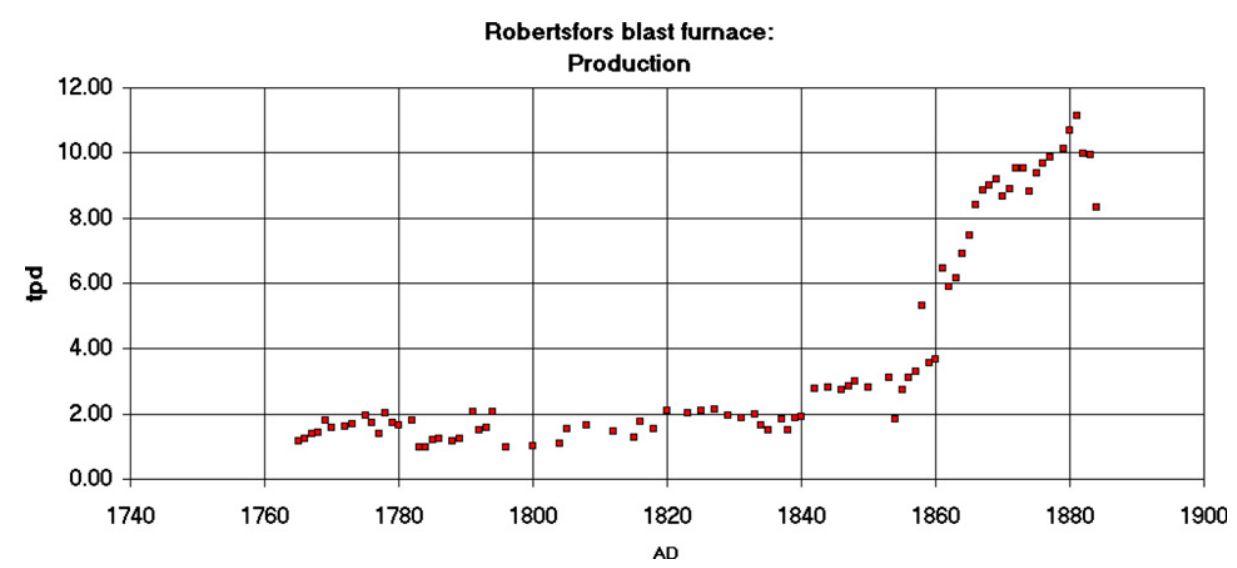

Fig. 4. Industrial learning curve from the past: Robertsfors lies in the forests of northern Sweden (charcoal, ore and salmon were available in plenty). 


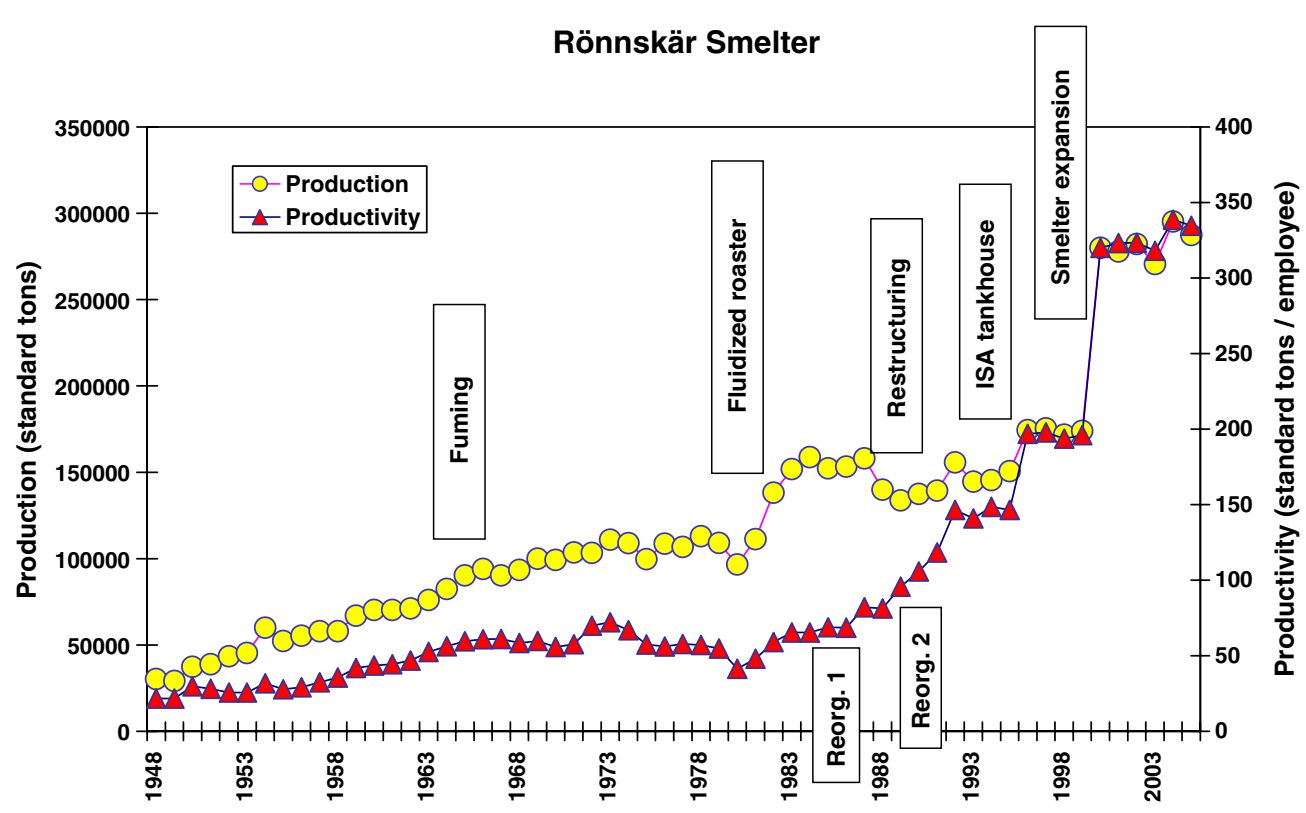

Fig. 5. Development of Boliden.

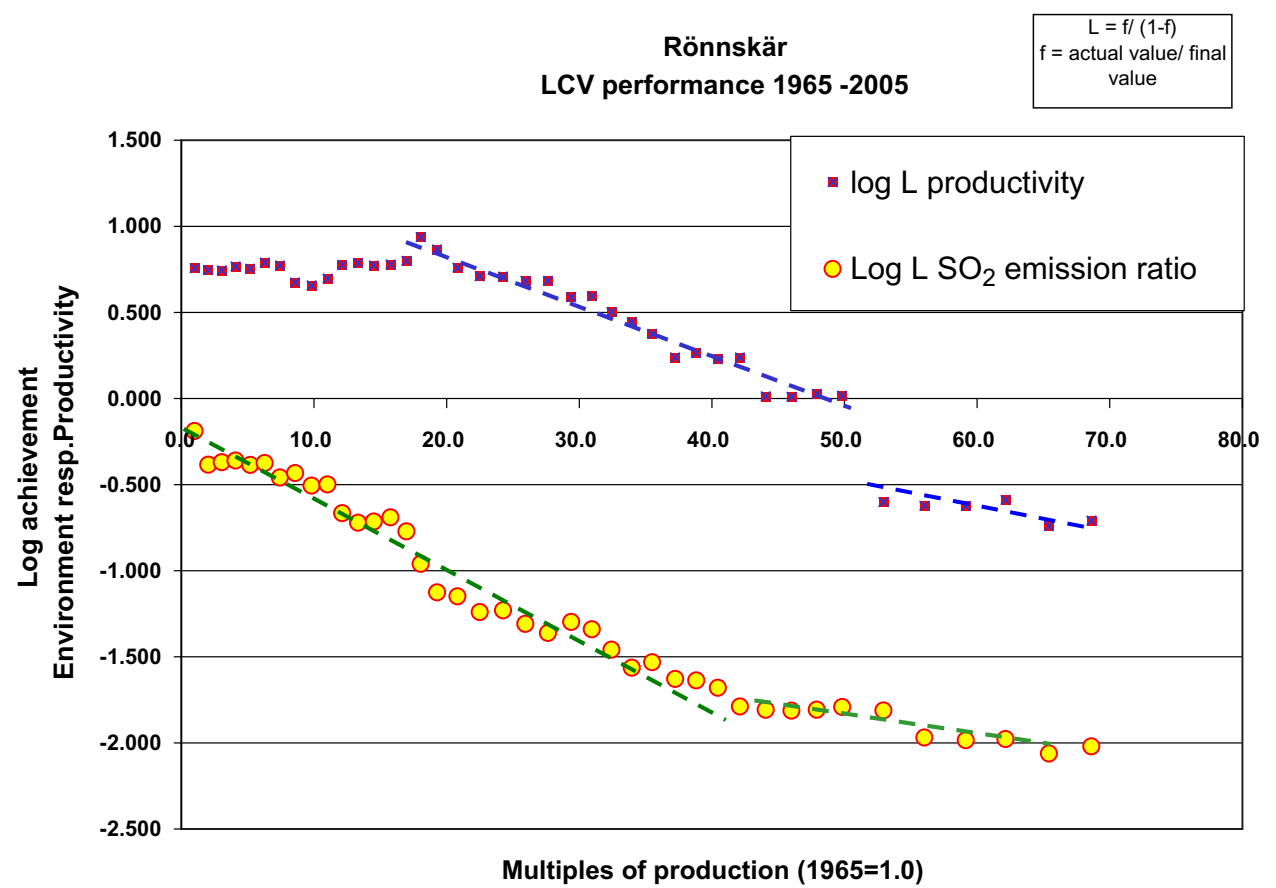

Fig. 6. Learning curve for productivity (expressed as hours per tonne) and environmental impact ( $\mathrm{SO}_{2}$ emissions tpa) of the Rönnskär Smelter.

\section{Production and use}

Boliden, as other competing companies in the business, continuously put lots of efforts to adjust existing processes, to exchange old processes - if necessary - and to develop or acquire new knowledge, well knowing that "Knowledge cannot replace resources. Knowledge are the resources!" (Gerholm, 1996). Our common stock of natural resources is at each moment in history limited by our common knowledge (Gerholm, 1996). Challenges include traditional issues such as: (i) access to raw materials, energy, land at competitive terms, (ii) personnel, knowledge and technology, (iii) acceptance of operations, and (iv) capital. Recently, new items have been added to the list, at least in Sweden, and increasingly in the EU (i) acceptance of products, and (ii) legal framework.

Acceptance of products manifests itself in the shape of lists for substances for surveillance, or as prohibitive lists 
(as a result of the former) of substances not to be used when building or repairing, statistics of "hazardous substances", as directives, or in broader terms in talks by researchers on "heavy metals". You guess right, that the production guys represented at this meeting are all subject of these lists, i.e., copper, zinc, nickel are on those lists. The zealots also include "new substances" such as silver and PGM's on their list. As industry, though, we should both promote wise old and new applications of our products. On the other hand, we should evaluate and phase out voluntarily unwise applications. One example of the latter is dispersing use of metals; such as lead in gasoline and in common paints. For other metals, we still have to value the benefit against the cost. For some metals, such as lead, with dominant applications, efficient recycling to minimize dispersing is easier to achieve. For others, efficient recycling may be more difficult due to the long life of some applications, or the nature of the application. Examples of the latter are losses from galvanizing protection layers, corrosion of protecting anodes of zinc. Yet other difficulties may stem from you and me! As consumers, we sometimes do easily dispose of contained, though small, metal values into the common rubbish bin. This shows off as metal content in waste streams, e.g., zinc.

$\begin{array}{ll}\text { - MSW (Municipal Solid Waste) } & 0.1-0.3 \% \\ \text { - MSW slag } & 0.2-0.6 \% \\ \text { - Waelz slag } & 2.6 \% \\ \text { - EAF (Electric Arc Furnace dust) II } & 8-15 \% \\ \text { - Jarosite } & <5 \% \\ \text { - BF (Blast Furnace) soot } & <2 \% \\ \text { - Tyres } & <2 \% \\ \text { - HH (Household) batteries } & 20 \%\end{array}$

For some of these streams, (e.g., EAF dust) solutions exist and are used for recycling, for others depicted by Fig. 7, you and I need a legal push to act. Current EU EoL (end of life) directives have initiated such pushes such as the waste electric and electronic equipment (WEEE) directive (WWW2), the end of life vehicle (ELV) directive (WWW3) and the battery directive (WWW4). Some these forced recycling streams may add substantially to the amount of e.g., copper available for recycling. It is the economic availability of metals for recycling that limits their recycling quota. Why should you recycle your household products or tear out the copper tubes and cables from the walls of your home the same year as you bought or installed them?

Of the waste streams depicted by Fig. 7, industrial, municipal and demolition waste need a lot of attention the coming years to solve sufficiently well. The others are really solved issues, especially also in view of appropriate legislation in place to assist in their recycling.

For the interested reader, it may be added that there were times when recycled streams were blamed for the decay of metal prices. The debate was very vivid in e.g., Mining and Metallurgy, Volume 12, 1931. Already then, it was recognized that primary copper smelters are the major vehicles for copper recycling, as their products are independently of the same high purity, whatever ratio of secondary copper is used.

To the list of abbreviations, we may add yet another R\&D-popular one i.e., life cycle assessment (LCA). Yet here a word of warning is in place! Again, we find a good summary in literature. Arrhenius (1988) summarized the facts in 1988. He probably already guessed that LCA also could stand for "Lots of Cash Available". He called the subject the dilemma of the scientist: to simplify and to risk wrong decisions or to give the whole complexity and not be understood by many. Applied to LCA: how can anybody claim to grasp the whole chain of industrial operations and express it in a two digit number? Where are the independent researchers in confessing that they left science and entered the field of "believing"? An example: using one of the available LCA tools for copper says: "It is better to extract copper by dirty processes from a rich mine than the opposite "Which naturally does not fit with our practice: we extract copper by methods with little environmental

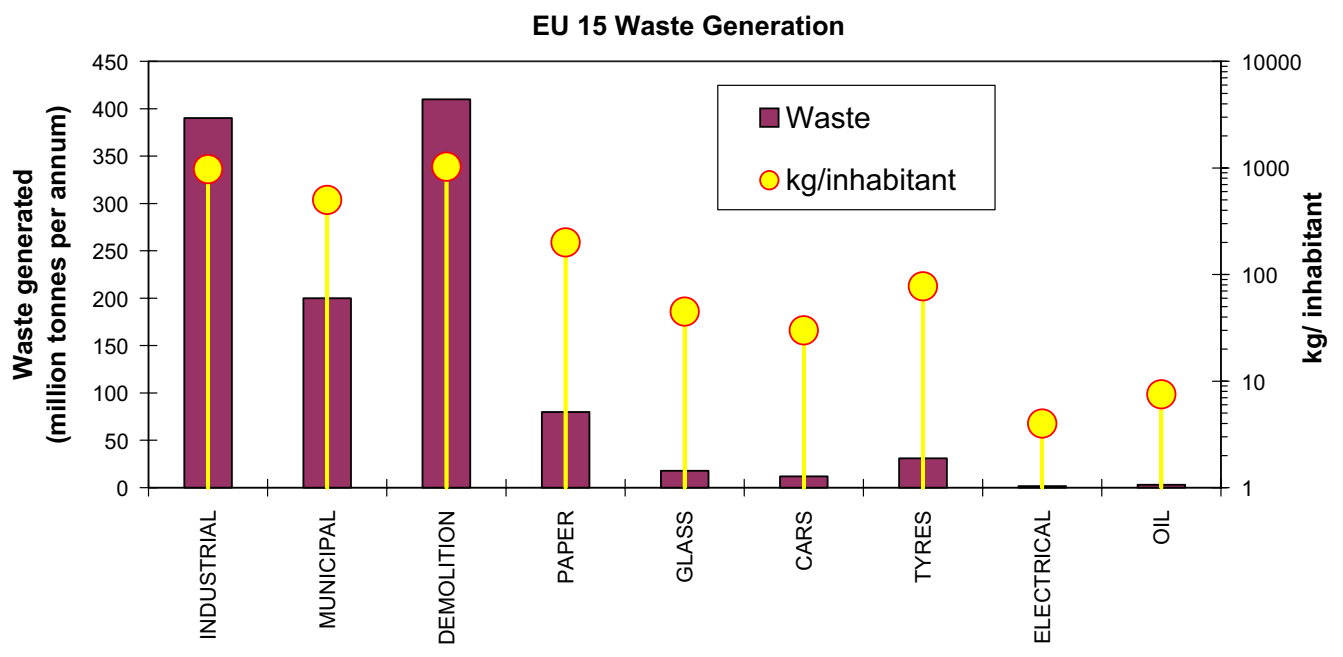

Fig. 7. Waste generation within the EU15. 


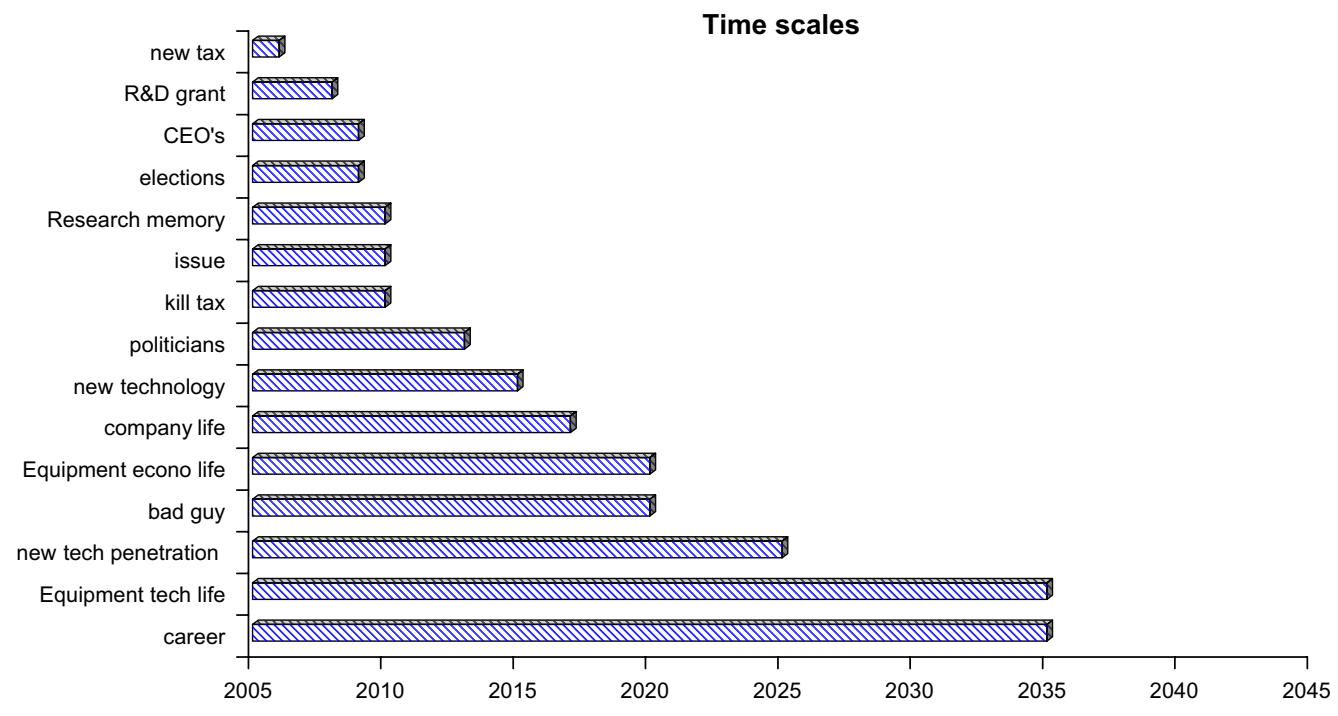

Fig. 8. Time scales of industrial impact factors.

impact from low ore grades." Yet for the satisfaction of the LCA'ers we also have to import concentrates from some rich mines abroad.

\section{Challenges and opportunities}

We can start in formulating our basic needs for 2020 i.e., the same as today! (i) Food, water, comfortable temperature, space, shelter, (ii) health and care, medicine, (iii) space for waste (personal and industrial), (iv) stimuli for our mind and social nature, and (v) lust for life. The latter has been thoughtfully described in 1950 by Teilhard de Chardin (1967):" thousands of engineers and economist are engaged in the scarcity of world resources such as coal, oil or uranium - while there is nobody concerned about watching the human lust for life: to check it's "temperature", to nourish it and to (why not?) increase it". I suggest that every doomsday prediction, paper, article or interview about the environment, health or safety be concluded:" By the way - there is a future!"

The reason: today's main challenge for our industry is the negativism, partly due to long wealth created by, you guess, by the industry. History is full of achievements by man (and women) with strong visions. For our industry we may think of some goals we want to achieve. As you guess, my points are colored by my personal experience.

\section{My vision}

Beside my hope that global poverty has been substantially reduced, that we live in peace, free from famine and have escaped pandemics, with address to mining and metallurgy I dream of the following:

- We are full of optimism and have a strong lust for life. - 2030: Europe is still going strong! And has established a lasting and fruitful cooperation with Africa.
- We are aware of and esteem the access to European strategic raw materials, including mines, recycling and know how.

- We value waste as a resource - networks and the science of waste re-use and recycling has made new resources viable.

- Legislation assists by challenging but achievable goals.

- Society appreciates and makes use of the experience in industry, listens and saves the forests (by cutting bureaucracy to $20 \%$ compared to 2007 ).

- Industry does not cry wolf too many times.

- And we are the employer of choice.

The way forward, especially with the time scales sketched in Fig. 8 in mind, contains many proposals to be solved early, i.e., as soon as possible.

\section{Road map for the future}

- Networks! Interaction! Broad education!

- Free and fair trade! No waste dumping but trade with waste for documented recovery.

- Stable economical and political conditions for our industry: industry needs access to a certain amount of feed over a payback period.

- This could solve issues like recycling of household batteries, glass and CRT's, fluff. Consequence: conservation of natural resources.

- Cooperation within $\mathrm{R} \& \mathrm{D}$, lobbying and promoting our products for old and new applications and for new processes with higher energy efficiency at lower unit cost.

- Cost-benefit analysis of impact factors such as transportation (today waste transportation accounts for approx $5 \%$ of trucking volumes).

- Consolidation of operations, but with attendance that "small can be beautiful". 
- Competition, commodization and consolidation - well established early warning systems and benchmarking, but also open doors policy, gives competitive advantages.

- Fundamental research, e.g., in thermodynamics chemical metallurgy, transport phenomena, kinetic, unit processes, combustion technology and (maybe) life cycle cost thinking.

$\ldots$ and a promise

- New Boliden will continue to be a European Leader in as well mining, smelting and recycling!

\section{Acknowledgements}

The author wants to thank Prof. Dr. Markus Reuter, Ausmelt, for suggesting the theme and kindly editing the paper, to Johan Wiklund, Boliden, Dr. John Floyd, Ausmelt, and Dr. Cajsa Samuelsson, Lulea Technical University, for valuable comments, to my wife Gunilla for continued support.

\section{References}

Arden, H., Wall, S., 1990."Wisdomkeepers”, ISBN 0-941831-66-3.

Arrhenius, E. 1988."Naturvetarens dilemma - förenkla och luras eller bli oförstådd" ("The Scientists dilemma - simplify and lure or remain misunderstood") Energiforskningsnytt nr 3.
De Geus, A., 1999."The Living Company" London, ISBN 1-85788-185-0.

Eliot in "The Rock" $1934<$ http://wwwpersonal.si.umich.edu/ nsharma/ dikw_origin.htm>.

Gerholm, T.R., 1996. "Limited natural resources or limited knowledge?" (in Swedish) in: "Kunskap I kamp mot kris", The Royal Swedish Academy of Sciences.

MMSD (Duma Nukosi ed.), ISBN 1-85383-907-8: "Breaking new ground" The Report of the Mining, Minerals and Sustainable Development Project May $2002<$ http://www.wbcsd.org/DocRoot/ ev8jEJvTiMYd4mJhGGHQ/finalmmsdreport.pdf>.

Lindström, L., 2002."The environmental history of the Falun Mine", 2002, ISBN 91-631-3536-1.

Teilhard de Chardin, P., 1967. L'Activation de l'energie Translation. Walter Verlag, Olten.

Van Hise, C.R., 1916. "The Conservation of Natural Resources in the United States" cited. In: Richard T., (Eds.), Ely "Conservation and Economic Theory" Trans AIME Vol LIV, pp.458-473.

Victor, D.G., 2006. Recovering Sustainable Development. Foreign Affairs 85 (1), 91-103.

WWW1: <http://www.selfknowledge.com/108259.htm>, <http://everything2.com/index.pl?node $\mathrm{id}=361216 \&$ displaytype $=$ printable $>$, http://en. wikipedia.org/wiki/Wisdom, <http://www.systems-thinking.org/dikw/ dikw.htm>.

WWW2: <http://europa.eu.int/eur-lex/pri/en/oj/dat/2003/1_037/1_03720030213en00240038.pdf>.

WWW3: <http://europa.eu.int/eur-lex/pri/en/oj/dat/2000/1_269/1_26920001021en00340042.pdf >.

WWW4: <http://eur-lex.europa.eu/LexUriServ/site/en/oj/2006/1_266/__ 26620060926en00010014.pdf>. 